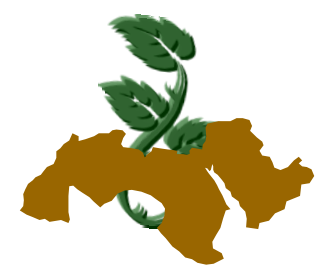

Arab Univ.

J. Agric. Sci., Ain Shams Univ., Cairo, 21(2), 219 - 233, 2013

\title{
MUTUAL EFFECT BETWEEN THREE ORANGE CVS. AND SOUR ORANGE AND VOLKAMERIANA ROOTSTOCKSS IN NEWLY RECLAIMED LANDS
}

\author{
Omima M. El- Sayed ${ }^{1}$ \\ 1. Desert Research Center, Ministery of Agriculture and Reclamation Land, Cario, Egypt
}

Keywords: Citrus rootstocks, Fruit quality, Leaf mineral content, Orange cvs, Root system, Vegetative growth, Yield.

\section{ABSTRACT}

This study was carried out in Wadi EL- Technologia in Ismailia Governorate, Egypt, during 2010 and 2011 seasons. Washington Navel (N.O.), Valencia (V.O.) and Baladi orange (B.O.) trees budded on Sour orange (S.O.) and Volkamer lemon (V.L.) were grown in sandy soil under drip irrigation system from a well has salinty of (1100 ppm).This investigation aimed to study the effect of the two citrus rootstocks on vegetative growth, yield, fruit quality, leaf mineral content of the three studied scions as well as the effect of such scions on root system growth of both rootstocks. The obtained results indicated that, Volkamer lemon rootstock recorded the highest significant values of vegetative growth, yield and fruit quality except T.S.S\% and ascorbic acid content. Sour orange rootstock gave the highest significant effect on values of leaf mineral content (N, P, K, Mg, Fe, $\mathrm{Zn}$ and $\mathrm{Cu}$ ) however V.L. showed the highest significant value. while, Ca leaf content recorded insignificantly difference between both rootstocks. Leaf Mn, content was significantly the highest with S.O. in both seasons. Root fresh and dry weight were the highest significantly with V.L. rootstock. From the showed result, one can recorded that V.O. scion significantly increased the vigour of V.L. root fresh and dry weight. While, B.O. scion showed significantly the lowest vigoure of V.L. root fresh and dry weight. On the other hand, N.O. scion gave a midiate result between V.O. and B.O. scions on root fresh and dry weight.

\section{INTRODUCTION}

Citrus is grown in more than 100 countries in tropical, subtropical and Mediterranean climates. Citrus is the most important fruit tree corp in Egypt, with annual production of approximately 3,522, 953 tons.
Oranges are the most extensively produced citrus fruit about 2,401,051 tons represented about $68.15 \%$, according to the latest Statistics of Ministry of Agriculture, Egypt 2010.

Rootstocks have a vital importance in the quality of production and survival of citrus species.

Sour orange (Citrus aurantium L.) is the most common rootstock for citrus orchards in Egypt. Although Sour orange was considered a satisfactory rootstock for most citrus scion varieties, it had to be replaced in several countries as a result of its susceptibility of citrus Tristeza (Gregoriou and Economides, 1993 ).

Volkamer lemon (Citrus volkameriana) is a lemon hybrid, it produces the most tree vigorous growth for the scions and tolerant to Tristeza, but it is susceptible to citrus nematode and burrowing nematode (Davies and Albrigo, 1994).

The effect of rootstocks on growth parameters had been studied by many workers such as Valbuena (1994), El-sayed (1999) and Dawood (2001). They concluded that both of Volkamer lemon and Rangpur lime rootstocks exhibited the most vigor growth characterized by longer tree height, larger tree volume, thinner trunk and leaf number per tree of different citrus varieties. Zayan et al (2004) indicated that tree size, growth vigor and leaf number of Washington Navel orange were significantly affected by the used rootstock Volkamer lemon. On the other hand, trees budded on Sour orange rootstocks gave intermediate values with most growth parameters for leaves number per shoot. Khankahdani et al (2006) reported that scions on Volkamer lemon rootstock caused faster vegetative growth compared to the other rootstocks. El-kady et al (2007) reported that, Valencia orange on Volkamer lemon gave longer shoots with more number of leaves per shoot than those on Rangpure lime or Sour orange rootstocks. Bassal (2009) concluded that, trees budded on Sour orange showed higher vegetative growth parameters compared Cleopatra mandarin rootstocks. Abd-Alla (2011) reported that Volkamer lemon had the highest significant effect on plant growth parameters compared to the other rootstocks on Balady Limon Transplants. Alireza 
et al (2012) found that trees grafted on V.L. produced larger canopy volume than trees on the other rootstocks.

Gregoriou and Economides (1994) noticed that cumulative yields of Valencia orange trees on C. Volkameriana rootstock was significantly higher than those of trees on the other rootstocks. Tuzucu et al (1999) noted that the highest yields of Washington Navel orange was obtained from trees on C. Volkameriana. But Alireza et al (2012). conclude that"Queen orange trees grafted on 'Volkamer' lemon produced the highest cumulative fruit yields," said by

Mendilcioglu (1986) noted that fruit width and length of Satsuma were higher on Troyer citrange than on Sour orange rootstock. Monteverde et.al. (1988) found that C.volcameriana induced the best mean fruit weight for Valencia orange. Monteverde (1989) reported that the smallest fruit of Valencia orange were produced on Cleopatra mandarin rootstock and peel thickness of Valencia orange was greater on C.Volkameriana and Sour orange than on Cleopatra mandarin rootstocks. Bassal (2009) and Alireza et al (2012) found that fruit rind thickness was not significantly affected by rootstocks.

Baldry et al (1982) found that fruits from Valencia orange trees on $C$. volkameriana recorded less juice percentage than those on Sour orange. Monteverde (1989) stated that juice percentage of Valencia orange was high on Cleopatra mandarin and $C$. volkameriana.

Monteverde (1989) reported that T.S.S. percent of Valencia oranges was the highest on Sour orange. Abdalla et al (1978) found that fruits of Washington Navel orange trees on Sour orange had higher/juice vitamin C. than those on Rough Limon. Baldry et al (1982) reported that fruits of Valencia orange trees on C.volkameriana. had lower ascorbic acid content. Alireza et al (2012) concluded that fruit from trees on Sour orange had the highest soluble soilds while those from trees on Volkamer lemon were the lowest. Sayed et al (2003) stated that, Volkamer lemon registered the greatest leaf $\mathrm{N}, \mathrm{P}, \mathrm{K}, \mathrm{Fe}, \mathrm{Zn}$ and $\mathrm{Mn}$ contents. Hafez (2006) noticed that macronutrients (N, P and $\mathrm{K}$ ) in leaves recorded the highest values with the Sour orange rootstock seedlings. As for micronutrients ( $\mathrm{Fe}, \mathrm{Mn}$ and $\mathrm{Zn}$ ), the highest values in the leaves were recorded by Volkamer lemon. Khankahdani et al (2006) found, that the highest leaf $\mathrm{P}$ and $\mathrm{Cu}$ content were obtained from scions on Volkamer lemon and $\mathrm{Ca}$ on Sour orange. Abdolhossein et al (2012) reported that the highest total leaf $\mathrm{N}$ concentration was on Sour orange but the lowest was on Volkamer lemon rootstocks.

Nasser (2010) revealed that Volkamer lemon had the significantly highest fresh and dry weight of roots as comparing with Sour orange rootstock. Abd-Alla (2011) found that root fresh weight had the highest significant value with Volkamer lemon and seedy lime seedling, but root dry weight had the lowest significant value with Troyer citrange.

The objective of this study was to evaluate the effect of Sour orange and Volkamer lemon rootstocks on the vegetative parameters, yield, fruit quality and leaf mineral content of Washington Navel, Valencia and Baladi orange trees. The study defined the most proper and suitable rootstocks for the three studied orange cvs. which achieved the highest tree yield and better fruit quality in newly reclaimed sandy soil . In addition the effect of the considered orange cvs. on root system growth of both studied rootstocks was studied.

\section{MATERIALS AND METHODS}

A field experiment was carried out in Wadi ElTechnologia in Ismailia Governorate, Egypt, during two successive seasons 2010 and 2011. Six years old Navel orange (N.O.), Valencia orange (V.O.) and Balady orange ( B.O.) trees budded on two citrus rootstocks, Sour orange (S.O.) (C.aurantium) and Volkamer Lemon ( C.volkameriana) (V.L.) .

However, the present experiment comprises three scions and two rootstocks and eash combination replicated three times with 3 trees for each replicate. Thus, 54 trees (18 N.O on 2 different rootstock +18 V.O. +18 B.O. on the same studied rootstocks) were arranged in a complete randomized block design. The selected trees had the same age, nearly uniform in height and branching and received unique agricultural practices.

Trees were planted in a newly reclaimed sandy soil at $5 \times 5$ meters under drip irrigation system from a well of salinity $1100 \mathrm{ppm}$. Soil analysis were carried out according to the methods of Jackson (1967), and Black (1965).Soil analysis is presented in Table (1) (A \& B).

\section{The following parameters were recorded}

\section{Tree vigour measurements}

In November of each season, the following measurements were carried out : Tree height (m),canopy diameter (m),canopy circumference (m) and canopy volume $\left(\mathrm{m}^{3}\right.$ ) ( calculated according to the equation reported by Morse and Robertson (1987). Canopy volume $=0.5236 \times \mathrm{HD}^{2}$, where $\mathrm{H}=$ tree height $(m)$ and $D=$ canopy diameter $(m)$.

\section{Vegetative growth flushes}

The current growth cycles which developed on the studied trees throughout the season were counted every year to study the intensity of vegetative growth of spring, summer and autumn flushes as affected by the used rootstock . 
Table 1. Physical and chemical analyses of the experimental soil samples.

A- Physical analysis

\begin{tabular}{|cccccccc|c|}
\hline $\begin{array}{c}\text { Soil depth } \\
\mathbf{C m}\end{array}$ & $\begin{array}{c}\text { Coarse } \\
\text { sand }\end{array}$ & $\begin{array}{c}\text { Medium } \\
\text { Sand }\end{array}$ & $\begin{array}{c}\text { Fine } \\
\text { Sand }\end{array}$ & $\begin{array}{c}\text { Soil } \\
\text { texture } \\
\text { Class }\end{array}$ & $\begin{array}{c}\mathrm{CaCo}_{3} \\
\%\end{array}$ & $\begin{array}{c}\text { O.M } \\
\%\end{array}$ & PH & $\begin{array}{c}\text { Ec } \\
\text { Mmhos } / \mathbf{c m}\end{array}$ \\
\hline $0-30$ & 88.60 & 5.96 & 5.44 & Sandy & 0.63 & 0.29 & 6.9 & 0.46 \\
$30-60$ & 89.50 & 4.25 & 6.25 & Sandy & 0.71 & 0.18 & 7.1 & 0.37 \\
$60-90$ & 92.40 & 3.70 & 3.90 & Sandy & 1.20 & 0.10 & 7.9 & 0.33 \\
\hline
\end{tabular}

B- Chemical analysis

\begin{tabular}{|cccccccccc|}
\hline Soil depth & \multicolumn{4}{c}{ Cations( meq./L) } & \multicolumn{5}{c|}{ Anions( meq./L ) } \\
\cline { 2 - 9 } $\mathbf{c m}$ & $\mathbf{C a}^{++}$ & $\mathbf{M g}^{++}$ & $\mathbf{N a}^{+}$ & $\mathbf{K}^{+}$ & $\mathbf{S o 4}^{--}$ & $\mathbf{C l}^{-}$ & $\mathbf{H c o}_{3}{ }^{-}$ & $\mathbf{C o}_{3}{ }^{--}$ \\
\hline $0-30$ & 4.99 & 1.18 & 3.57 & 0.26 & 2.37 & 6.14 & 1.50 & ---- \\
$30-60$ & 4.80 & 0.70 & 3.91 & 0.46 & 2.66 & 4.76 & 2.38 & ---- \\
$60-90$ & 0.32 & 0.05 & 0.27 & 0.04 & 2.93 & 3.77 & 2.00 & ---- \\
\hline
\end{tabular}

\section{Yield}

Yield as fruit weight $\mathrm{kg} /$ tree was recorded at harvesting time for each season. It was determined at maturity stage when the percent of T.S.S/acid ratio reached about $9 \%$ (El- Hammady et al 1974).

\section{Fruit quality}

A sample of 25 fruits of each individual tree was taken randomly at harvesting time to determine the physical and chemical properties as follow.

\section{Fruit physical properties}

Fruit weight (g) - Pulp weight (g) - Fruit height and diameter $(\mathrm{cm})$ using a vernier caliper - Peel thickness $(\mathrm{mm})$ using a vernier caliper - Juice volume ( $\mathrm{ml}$ per fruit ).

\section{Fruit chemical properties}

* Total soluble solids percentage (T.S.S\%) was determined by using a hand refractometer.

* Total acidity and Vitamin C content in fruit juice were determined according to A.O.A.C (1990) .

* Total soluble solids / acid ratio was calculated by dividing T.S.S values on total acid values.

\section{Leaves mineral content}

* Nitrogen was determined by Microkjeldhl method ( Jakson, 1967).

* Phosphorus was determined by the method of (Kitson and Mellon,1964).

* Potassium and sodium were determined by the method of the flame photometer according to the method of (Brown and Lilleland, 1966).

* Calcium and mangnesium were determined by titration against versenate solution (Chapman and Pratt,1961).

* In addition, some micronutrients ( $\mathrm{Fe}, \mathrm{Mn}, \mathrm{Zn}$, and $\mathrm{Cu}$ ) were determined by using the atomic absorption spectrophotometer.

\section{Root fresh and dry weight ( kg}

At the end of the second growing season, three trees from each combination were evened out. Mean while, a square area of $5 \times 5 \mathrm{~m}$ around each tree was marked and its surface thoroughly evened out for $60 \mathrm{~cm}$ depth. The root system was excavated according to the method of Kolesnikov (1971).

Such experiment contained 3 orange cultivars $\mathrm{x} 2$ rootstocks $=6$ treatments in a factorizal experiment.

\section{Statistical analysis}

The obtained results were statistically analyzed using analysis of Variance and Duncan's 
multiple range test was use to differential means according to Snedecor and Cochran (1980).

\section{RESULTS AND DISCUSSION}

Data in Table (2) showed the effect of three orange cvs., two rootstocks and their interaction on tree growth in 2011 and 2012 seasons.

\section{a) Tree height (m)}

Concerning orange cvs., N.O and V.O. had higher significant value than B.O. Regarding rootstocks V.L. had higher significant value than S.O. The interaction between the two studies factors, the combination of N.O. and V.O. on V.L. gave the highest significant values in the first season. In the second season, concerning orange cvs., B.O. recorded the lowest significant value.
Regarding rootstocks, V.L. had higher significant value than S.O.. The interaction between the two studied factors, combination of N.O. and V.O.on V.L. gave the higher significant values except V.O.on S.O. rootstock.

\section{b) Canopy diameter (m)}

In the first season, concerning orange cvs., insignificant differences among combination could be noticed. But in the second season V.O. gave the highest significant value. Regarding rootstocks, V.L. had higher significant value than S.O.in the second season only. The interaction between the two studies factors, in the first season, insignificant differences among combination were recorded. In the second season the lowest significant value was recorded by N.O. cv.on S.O. rootstock.

Table ( 2 ) Effect of three orange cvs, two rootstocks and their interaction on tree growth in 2010 and 2011 season.

\begin{tabular}{|c|c|c|c|c|c|c|c|c|c|c|c|c|}
\hline \multirow{2}{*}{$\begin{array}{l}\text { parameter } \\
\quad \mathrm{S} \\
\text { Rootstocks } \\
\text { cultivars }\end{array}$} & \multicolumn{2}{|c|}{$\begin{array}{l}\text { Tree height } \\
\text { (m) }\end{array}$} & \multirow{2}{*}{$\begin{array}{c}\text { Mea } \\
n\end{array}$} & \multicolumn{2}{|c|}{$\begin{array}{l}\text { Canopy diameter } \\
(\mathrm{m})\end{array}$} & \multicolumn{3}{|c|}{$\begin{array}{c}\text { Canopy } \\
\text { circumference } \\
(\mathrm{m})\end{array}$} & \multirow{2}{*}{ Mean } & \multicolumn{2}{|c|}{$\begin{array}{l}\text { Canopy volume } \\
\qquad\left(\mathrm{m}^{3}\right)\end{array}$} & \multirow{2}{*}{ Mean } \\
\hline & S.O & V.L & & S.O & V.L & $\begin{array}{c}\text { Mea } \\
\mathrm{n}\end{array}$ & S.O & V.L & & S.O & V.L & \\
\hline $\begin{array}{c}\text { Navel } \\
\text { orange }\end{array}$ & $\begin{array}{c}1.9 c \\
d\end{array}$ & $2.2 a$ & $2.0 \mathrm{~A}$ & $2.0 \mathrm{a}$ & $2.0 \mathrm{a}$ & $2.0 \mathrm{~A}$ & $5.3 d$ & $5.8 b$ & $5.5 \mathrm{~B}$ & $3.8 \mathrm{de}$ & $4.4 a b$ & 4.1B \\
\hline $\begin{array}{l}\text { Valencia } \\
\text { orange }\end{array}$ & $2.0 \mathrm{c}$ & $2.2 a$ & $2.1 \mathrm{~A}$ & $2.1 \mathrm{a}$ & $2.1 \mathrm{a}$ & $2.1 \mathrm{~A}$ & $5.4 \mathrm{~cd}$ & $6.0 \mathrm{a}$ & $5.7 \mathrm{~A}$ & 4.1cd & $4.5 a$ & $4.3 A$ \\
\hline $\begin{array}{l}\text { Baladi } \\
\text { orange }\end{array}$ & $1.9 \mathrm{~d}$ & $2.1 b$ & $2.0 \mathrm{~B}$ & $2.0 \mathrm{a}$ & $2.1 \mathrm{a}$ & $2.0 \mathrm{~A}$ & $5.3 d$ & $5.5 c$ & $5.4 \mathrm{C}$ & $3.8 e$ & $4.2 \mathrm{bc}$ & $4.0 \mathrm{~B}$ \\
\hline Mean & $1.9 \mathrm{~B}^{\backslash}$ & $2.1 A^{\prime}$ & & $2.0 A^{\prime}$ & $2.06 A^{\prime}$ & & $5.3 B^{\backslash}$ & $5.7 A^{\prime}$ & & $3.9 \mathrm{~B}^{\backslash}$ & $4.4 A^{\prime}$ & \\
\hline $\begin{array}{l}\text { Navel } \\
\text { orange }\end{array}$ & $2.3 b$ & $2.4 a$ & $2.3 \mathrm{~A}$ & $2.3 \mathrm{c}$ & $2.4 a b$ & 2.3B & $5.6 d$ & $6.1 \mathrm{ab}$ & $5.7 \mathrm{~B}$ & $5.2 \mathrm{c}$ & $5.7 b$ & $5.5 B$ \\
\hline $\begin{array}{l}\text { Valencia } \\
\text { orange }\end{array}$ & $\begin{array}{c}2.3 a \\
b\end{array}$ & $2.4 a$ & $2.4 \mathrm{~A}$ & $2.4 a$ & $2.4 a$ & $2.4 \mathrm{~A}$ & $5.7 \mathrm{bcd}$ & $6.3 a$ & $6.0 \mathrm{~A}$ & $5.6 b$ & $6.0 \mathrm{a}$ & $5.8 A$ \\
\hline $\begin{array}{l}\text { Baladi } \\
\text { orange }\end{array}$ & $2.1 c$ & $2.7 b$ & $2.2 \mathrm{~B}$ & $2.3 b c$ & $2.4 a$ & 2.3B & $5.6 \mathrm{~cd}$ & $5.8 \mathrm{bc}$ & $5.7 \mathrm{~B}$ & $4.9 d$ & $5.5 b$ & $5.2 \mathrm{C}$ \\
\hline Mean & $2.2 \mathrm{~B}^{\backslash}$ & $2.4 A^{\prime}$ & & $2.3 B^{\prime}$ & $2.4 A^{\prime}$ & & $5.5 \mathrm{~B}^{\prime}$ & $6.1 A^{\prime}$ & & $5.2 A^{\prime}$ & $5.7 A^{\prime}$ & $5.5 \mathrm{~B}$ \\
\hline
\end{tabular}

Means having the same letter (S) in each column, row and interaction are not significant at $5 \%$ level. $\mathrm{S} . \mathrm{O}=$ Sour Orange . - V.L = Volkamer lemon. Parameters were measured in Nov. of both seasons

\section{c) Canopy circumference (m)}

Concerning orange cvs., V.O. recorded the highest significant value in both seasons. Regarding rootstocks, V.L. gave higher significant value than S.O. in both seasons. The interaction between the two studied factors showed highest significant value with the combination of V.O. on V.L. in both seasons.

\section{d) Canopy volume $\left(\mathrm{m}^{3}\right)$}

Concerning orange cvs., V.O. gave the highest significant value in both seasons. Regarding rootstock, V.L. recorded higher significant value than S.O. in the first season only. The interaction between the two studied factors, the combination of
V.O. cv. on V.L. gave the highest significant value in both seasons, except the combination of N.O. CV. on V.L. in the first season only.

Data in Table (3) showed the effect of three orange cvs., two rootstocks and their interaction on leaf number / shoot in different vegetative growth flushes of orange trees in 2010 and 2011 seasons.

\section{a) Spring growth flush}

Concerning orange cvs., N.O. recorded the highest significant value in both seasons. Regarding rootstocks V.L. had higher significant value than S.O. in both seasons. The interaction between the two studied factors, all orange cvs. budded on V.L. roorstock had highest significant values in both seasons. 
Table 3. Effect of three orange cvs., two rootstocks, and their interaction on leaf number / shoot in differen vegetative growth flushes in 2010 and 2011 seasons.

\begin{tabular}{|c|c|c|c|c|c|c|c|c|c|}
\hline \multirow{3}{*}{$\begin{array}{l}\text { Parameters } \\
\text { Rootstocks } \\
\text { Cultivars }\end{array}$} & \multicolumn{9}{|c|}{ Growth flush } \\
\hline & \multicolumn{2}{|c|}{ Spring } & \multirow{2}{*}{ Mean } & \multicolumn{2}{|c|}{ Summer } & \multirow{2}{*}{ Mean } & \multicolumn{2}{|c|}{ Autumn } & \multirow{2}{*}{ Mean } \\
\hline & S.O & V.L & & S.O & V.L & & S.O & V.L & \\
\hline \multicolumn{10}{|c|}{ first season } \\
\hline \multirow{4}{*}{$\begin{array}{l}\text { Navel orange } \\
\text { Valencia } \\
\text { orange } \\
\text { Baladi } \\
\text { orange } \\
\text { Mean }\end{array}$} & $7.2 b$ & $8.9 a$ & $8.1 \mathrm{~A}$ & $8.9 c$ & $10.1 \mathrm{a}$ & $9.5 \mathrm{~A}$ & $8.2 b$ & $9.1 \mathrm{a}$ & $8.6 \mathrm{~A}$ \\
\hline & $6.8 b$ & 8.3a & $7.6 \mathrm{~B}$ & $8.0 d$ & $9.9 a b$ & $9.0 \mathrm{~B}$ & $7.0 \mathrm{c}$ & $8.5 a b$ & $7.7 \mathrm{~B}$ \\
\hline & $7.0 \mathrm{~b}$ & $8.6 a$ & $7.8 \mathrm{~B}$ & $8.0 d$ & $9.6 b$ & $8.8 \mathrm{~B}$ & $7.3 \mathrm{c}$ & 8.3ab & $7.8 \mathrm{~B}$ \\
\hline & $7.0 \mathrm{~B}^{\prime}$ & $8.6 A^{\prime}$ & \multicolumn{4}{|c|}{$\begin{array}{c}8.3 B^{\prime} \quad 9.8 A^{\prime} \\
\text { seconds season }\end{array}$} & $7.5 B^{\prime}$ & $8.6 A^{\prime}$ & \\
\hline Navel orange & $7.5 b$ & $8.8 a$ & $8.2 \mathrm{~A}$ & $8.6 b$ & $10.0 \mathrm{a}$ & $9.3 \mathrm{~A}$ & $8.6 b$ & $9.6 a$ & $9.0 \mathrm{~A}$ \\
\hline $\begin{array}{l}\text { Valencia } \\
\text { orange }\end{array}$ & 7.3bc & $8.6 a$ & 7.9AB & $8.2 b$ & $9.6 a$ & 8.9AB & $7.2 \mathrm{c}$ & $8.3 b$ & $7.7 \mathrm{~B}$ \\
\hline Baladi & $7.1 \mathrm{c}$ & $8.6 a$ & $7.8 \mathrm{~B}$ & $7.9 \mathrm{~b}$ & $9.4 a$ & 8.7B & $7.5 \mathrm{c}$ & $8.5 b$ & $8.0 \mathrm{~B}$ \\
\hline Mean & $7.3 \mathrm{~B}^{\prime}$ & $8.7 A^{\prime}$ & & $8.2 B^{\prime}$ & $9.7 A^{\prime}$ & & $7.7 \mathrm{~B}^{\prime}$ & $8.8 A^{\prime}$ & \\
\hline
\end{tabular}

Means having the same letter (S) in each column, row and interaction are not significant at $5 \%$ level.

$S . O=$ Sour Orange. - V.L = Volkamer lemon

\section{b) Summer growth flush}

Concerning orange cvs., N.O. had the highest significant value in both seasons. Regarding rootstocks, V.L. gave higher significant value than S.O. in both seasons. The interaction between the two studied factors, revealed that combination of N.O. on V.L. showed the highest significant value in the first season. In the second one, the combination of all orange cvs. on V.L. rootstock recorded the highest significant values.

\section{c) Autumn growth flush}

Concerning orange cvs., N.O. had the highest significant value in both seasons. Regarding rootstock, V.L. gave higher significant value than S.O. in both seasons. The interaction between the two studied factors, showed that combination of N.O. on V.L. recorded the highest significant value in both seasons.

The obtained findings which cleared that number of leaves in all growth flushs of orange cvs. were the highest on V.L. rootstock are in line with those reported by Dawood (2001), Zayan et al (2004), El-Kady et al (2007), Bassal (2009), AbdAlla (2011) and Alireza et al (2012). They found that V.L. rootstock caused faster vegetative growth compared to the other rootstocks and leaf number of N.O. were significantly affected by the used rootstock V.L.

Data in Table (4) showed the effect of three orange cvs., two rootstocks and their interaction on tree yield $(\mathrm{kg})$ and some fruit physical characteristics in 2010 and 2011 seasons.

\section{a) Tree yield (kg / tree)}

Concerning orange cvs., N.O. had the highest significant yield per tree $(31.8 \mathrm{~kg} / \mathrm{tree})$. Regarding to rootstocks, V.L. gave higher significant value than S.O., (27.9\& $24.9 \mathrm{~kg} /$ tree) in the first and second season respectively. The interaction between the two studied factors, showed the highest significant value with the combination of N.O. cV. on V.L. rootstock $(33.5,35.2 \mathrm{~kg} /$ tree $)$ in the first and second season, respectively.

\section{b) Fruit weight (gm)}

Concerning orange cvs., N.O. gave the highest significant value in the first season but V.O. recorded the highest significant value in the second season. Regarding to rootstocks, V.L. recorded higher significant value than S.O. in both seasons. The interaction between the two studied factors, revealed that combination of N.O. on V.L. gave the highest significant value (228.6 \& $231.4 \mathrm{~g} /$ tree $)$ in the first and second season, respectively.

\section{c) Pulp weight (gm)}

Concerning orange cvs., N.O. and V.O. gave higher significant value than B.O. in both seasons. Regarding rootstocks, V.L. showed higher significant value than S.O. in both seasons. The interaction between the two studied factors, showed the highest significant values with combination of N.O. and V.O. cvs. on V.L. rootstock (152.8 \& $143.8 \mathrm{gm}$ ) in the first season, respectively. 
In the second season, the interaction between the two studied factors, showed that N.O. on V.L. resulted the highest significant value.

\section{d) Fruit height (cm)}

In both seasons, regarding orange cvs., N.O. gave the highest significant value. Concerning rootstock, V.L. had higher significant value than S.O..The interaction between the two studied factors, revealed N.O. cv. on V.L. that rootstock obtained higher significant value in the first season and was higher than most of other combinations in the second one.

\section{e) Fruit diameter (cm)}

Regarding orange cvs., N.O. gave the highest significant value in the first season but V.O. had the highest significant value in the second season. Concerning rootstocks, V.L. had higher significant value than S.O. in the first season but S.O. recorded higher significant value than V.L. in the second one. The interaction between the two studied factors, showed that N.O. cv. on V.L. rootstock showed higher significant value than most of other combinations.

\section{f) Peel thickness ( $\mathrm{mm}$}

In the first season, concerning orange cvs., insignificant differences among combination could be noticed. Regarding rootstock, V.L. showed higher significant value than S.O..The interaction between the two studied factors, had higher significant values with combination of V.O. and B.O. on V.L. rootstock than all orange cvs. budded on S.O. rootstock. In the second season concerning orange cvs., N.O. and V.O. had higher significant value than B.O.. Regarding rootstocks, V.L. and S.O. recorded insignificant difference between them. The interaction between the two studied factors, revealed higher significant values with combinations of N.O. and V.O. cvs. on V.L. rootstock than all orange cvs. budded on S.O. rootstock.

\section{g) Juice volume/fruit (ml)}

In the first season, concerning orange cvs., V.O. and B.O. gave higher significant value than N.O. Regarding rootstock V.L. showed higher significant value than S.O. rootstock. The interaction between the two studied factors, showed the highest significant value with combination of V.O. cV. with V.L. rootstock $(116.40 \mathrm{ml})$. In the second season, concerning orange cvs., V.O. gave the highest significant value. Regarding rootstock V.L. recorded higher significant value than S.O. rootstock. The interaction between the two studied factors, revealed V.O. cv. on V.L. obtained the highest significant value $(118.00 \mathrm{ml})$.
These results are in harmony with those found by Tuzucu et al (1999) and Alireza et al (2012) on Navel and Queen orange. They found that the highest yields were obtained from trees on $C$. volkameriana.

Results of fruit physical characteristics were in agreement with those found by Monteverde et al (1988) who found that V.L. induced the best fruit weight of Valencia orange, Mendilicioglu (1986) noted that fruit width and length of Satsuma were higher on Troyer citrange that on Sour orange rootstock. Monteverde (1989) reported that peel thickness of V.O. was greater on V.L. and S.O. than on Cleopatra mandarin rootstocks.

On the other hand, Bassal (2009) and Alireza etal (2012) found that fruit rind thickness wasn't significantly affected by rootstocks. Montedevrde (1989) found that percentage juice of Valencia orange was high on C.volkameriana.

Data in Table (5) showed the effect of three orange cvs, two rootstocks and their interaction on some fruit chemical properties in 2010 and 2011 seasons.

\section{a) T.S.S \%}

Concerning orange cvs., V.O. recorded the highest significant value in both seasons. Regarding rootstock, S.O. gave higher significant value than V.L.. in both seasons. The interaction between the two studied factors, showed that combination of V.O. on S.O. had the highest significant value in both seasons.

\section{b) Total acidity $\%$}

Concerning orange cvs., B.O. had the highest significant value in both seasons. Regarding rootstock, V.L. recorded higher significant value than S.O. in both season. The interaction between the two studied factors, revelaed that combination of B.O. on V.L. gave the highest significant value in both seasons.

\section{c) T.S.S. / acid ratio}

Concerning orange cvs., V.O. gave the highest significant value in both seasons. Regarding rootstock, S.O. recorded higher significant value than V.L. in both seasons. The interaction between the two studied factors, revelaed that combination of V.O. on S.O. gave the highest significant value in both seasons.

\section{d) Ascorbic acid content ( $\mathrm{mg} / 100 \mathrm{ml}^{3}$ juice)}

In the first season, concerning orange cvs., insignificant differences among different combina tions could be noticed. But in the second season 
Table 5. Effect of three orange cvs, two rootstocks and their interaction on some fruit chemical properties in 2010 and 2011 seasons.

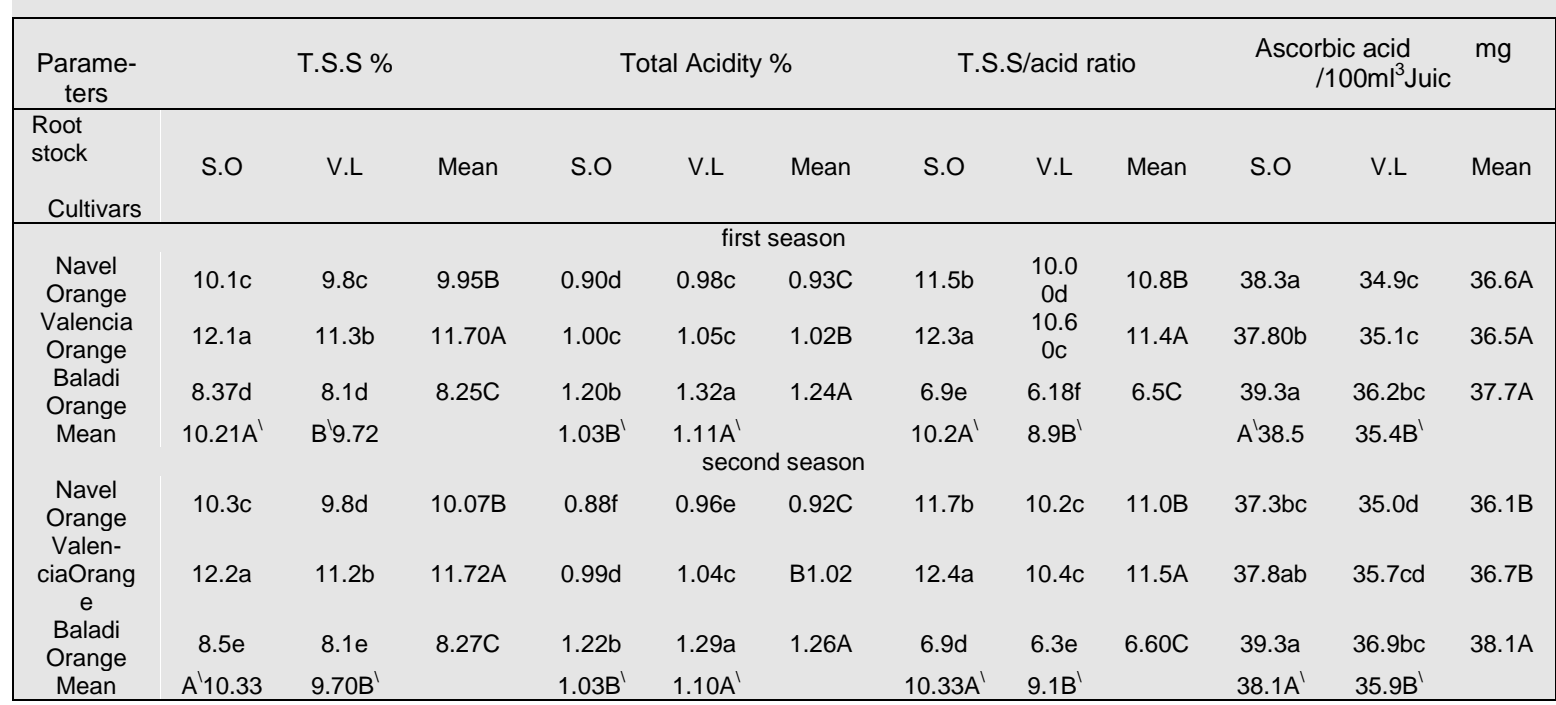

Means having the same letter $(S)$ in each column, row and interaction are not significant at $5 \%$ level.

S.O = Sour Orange. - V.L = Volkamer lemon.

B.O. gave the highest significant value. Regarding rootstocks S.O. had higher significant value than V.L. in both seasons. The interaction between the two studies factors, in first the season combinations of N.O. and B.O. cvs. on S.O. rootstock showed the highest significant values. In the second season, the highest significant value was recorded by B.O. cv. on S.O. rootstock except V.O. on S.O. rootstock.

These results are in agreement with these obtained by Montevrde(1989) and Alireza et al (2012) who found that T.S.S and T.S.S / acid ratio percentage of V.O. cV. was fruits the highest on S.O. rootstock, Abdalla et .al.(1978) found that fruit of Navel orange trees on S.O. rootstock had higher juice vitamin $\mathrm{C}$. content than those on Rough Limon.

Data in Table (6) showed the effect of three orange cvs., two rootstocks and their interaction on leaf macro element content in 2010 and 2011 seasons.

\section{a) $\mathrm{N} \%$}

Regarding orange cvs., V.O. resulted the highest significant values in both seasons. Concerning rootstock V.L. obtained higher significant values than S.O. in both seasons. The interaction between the two studied factors, postulated that combination of V.O. on V.L. showed the highest significant values in both seasons except V.O. with S.O. in the second season.

\section{b) $\mathbf{P} \%$}

In the first season, concerning orange cvs., V.O. and B.O. gave higher significant vales than N.O.. Regarding rootstock, V.L. had higher significant value than S.O.. The interaction between the two studied factors, proved that combinations of N.O. and V.O. on V.L. obtained the highest significant values except V.O. on S.O.. In the second season, Regarding orange cvs., N.O. and V.O. resulted higher significant values than B.O.. Concerning rootstock, V.L. showed higher significant value than S.O.. The interaction between the two studied factors, showed that combinations of of N.O. and V.O. on V.L. exhibited the highest significant values except V.O. on S.O..

\section{c) $\mathrm{K} \%$}

Concerning orange cvs., V.O. had the highest significant value in both seasons. Regarding rootstock, V.L. gave the highest significant value in both seasons. The interaction between the two studied factors, revealed that in the first season, combination of V.O. on V.L. had the highest significant value. But in the second season combination of V.O. on S.O. and V.L. had the highest significant value.

\section{d) $\mathrm{Ca} \%$}

In the first season, regarding orange cvs., V.O. and B.O. leaves had higher significant value than N.O.. Concerning rootstock, insignificant difference between both rootstocks could be noticed. The interaction between the two studied factors, 
Mutual effect between three orange cvs. and sour orange and volkameriana rootstockss 227 in newly reclaimed lands

Arab Univ. J. Agric. Sci., 21(2), 2013 
revealed that combinations of N.O. on S.O. gave lower significant value than most of other combinations. In the second season, concerning orange cvs., N.O. and V.O. had higher significant value than B.O.. Regarding rootstock, insignificant difference between both rootstocks could be noticed. The interaction between the two studied factors, showed that combinations of B.O. with S.O. had lower significant value than most of other combinations.

\section{e) $\mathrm{Mg} \%$}

Regarding orange cvs., V.O. and B.O. had higher significant value than N.O. in both seasons. Concerning rootstock, V.L. gave higher significant value than S.O. in both seasons. The interaction between the two studied factors, in the first season postulated that combination of B.O. with V.L. recorded the highest significant value except V.O. with V.L.. But in the second season combination of N.O. with S.O. obtained the lowest significant value.

These results are in harmony with these found by Sayed et al (2003) and Khankahdani et al (2006) They stated that, Volkamer Lemon registered the greatest leaf $N, P, K$ contents while, $\mathrm{Ca}$ leaf content recorded insignificant difference between both rootstocks. On the other hand, these results are in disagreement with those found by Hafez(2006) and Abdolhossein et al (2012) who noticed that (N,P and $K$ ) in leaves recorded the highest values with the Sour orange rootstock seedling .

Data in Table (7) showed the effect of three orange cvs., two rootstocks and their interaction on scion leaf micro elements contents in 2010 and 2011 seasons.

\section{a) Fe ppm}

Concerning orange cvs., V.O. recorded the highest significant value in both seasons. Regarding rootstock, V.L. gave higher significant value than S.O. in both seasons. The interaction between the two studied factors, proved that combinations of V.O. on V.L. showed the highest significant value in both seasons.

\section{b) Mn ppm}

Regarding orange cvs., V.O. gave the highest significant value in both seasons. Concerning rootstock, S.O. had higher significant value than V.L. in both seasons. The interaction between the two studied factors, revealed that combinations of V.O. on S.O. resulted in the highest significant value in both seasons.

\section{c) Zn ppm}

Concerning orange cvs., V.O. had the highest significant value in both seasons. Regarding rootstock, V.L. gave higher significant value than S.O. in both seasons. The interaction between the two studied factors, showed that combinations of V.O. on V.L. recorded the highest significant value in both seasons.

\section{d) Cu ppm}

Regarding orange cvs., V.O. showed the highest significant value in both seasons. Concerning rootstock, V.L. had higher significant value than S.O. in both seasons. The interaction between the two studied factors, proved that combinations of V.O. on V.L. recorded the highest significant value in both seasons.

These results are in harmony with those obtained by Sayed et al (2003), Hafez (2006) and Khankahdani et al (2006). They recorded that highest micronutrients, $\mathrm{Fe}, \mathrm{Zn}$ and $\mathrm{Cu}$ value in scion leaves were recorded on Volkamer lemon rootstock but highest value of $\mathrm{Mn}$ was noticed on Sour orange rootstock.

Data in Table (8) showed the effect of three orange cvs., rootstocks and their interaction on root fresh and dry weight $(\mathrm{kg})$ in 2011 season.

\section{a) Skeletal roots}

Concerning orange cvs., V.O. had the highest significant value in fresh and dry weight. Regarding rootstock, V.L. gave higher significant value than S.O.in fresh and dry weight. The interaction between the two studied factors, postulated that combinations of V.O. on V.L. recorded the highest significant value in fresh and dry weight.

\section{b) Semi-skeletal roots}

Concerning orange cvs., V.O. showed the highest significant value. Regarding rootstock, V.L. gave higher significant value than S.O.. The interaction between the two studied factors, showed that combinations of V.O. on V.L. recorded the highest significant values.

\section{c) Feeder roots}

Concerning orange cvs., V.O. had higher significant value than B.O. in fresh and dry weight. Regarding rootstock, V.L. recorded higher significant value than S.O. in fresh and dry weight. The interaction between the two studied factors, revealed that combination of V.O. on V.L. showed higher significant values than most of other combinations in fresh and dry weight. 
Mutual effect between three orange cvs. and sour orange and volkameriana rootstockss

in newly reclaimed lands

Arab Univ. J. Agric. Sci., 21(2), 2013 

in newly reclaimed lands

\section{c) Whole root system}

Concerning orange cvs., V.O. gave the highest significant value in fresh and dry weight. Regarding rootstock, V.L. had higher significant value than S.O.. The interaction between the two studied factors, proved that combination of V.O. on V.L. recorded the highest significant value in fresh and dry weight.

These results are in harmony with those found by Nasser (2010) and Abd-Alla (2011) who revealed that Volkamer Lemon had the significantly highest fresh and dry weight of roots as comparing with Sour Orange rootstock.

In conclusion, one can say that, Volkamer Lemon rootstock is the best and promosing rootstock for Valencia followed by Navel and Baladi orange trees under Wadi El-Technologia in Ismailia Governorate conditions, Egypt because it achieved the tallest trees, highest canopy diameter, highest canopy circumference, largest canopy volume, highest fruit and flesh weight. Also it gained the highest average yield / tree, highest fruit juice volume, greatest fruit highest, greatest fruit diameter, highest leaf mineral content and highest root fresh and dry weight.

From the showed result, one can recorded that V.O. scion significantly increased the vigour of V.L. root fresh and dry weight. While, B.O. scion showed significantly the lowest vigoure of V.L. root fresh and dry weight. On the other hand, N.O. scion gave a midiate result between V.O. and B.O. scions on root fresh and dry weight.

\section{REFERENCES}

A.O.A.C. (1990): Association of Official Agricultural Chemists Official and Tentative.

Abd alla, K.M.; Meligi, M.A. and Kouka, H.M. (1978): Influence of different rootstocks on yield and fruit properties of regenerated Washington Navel orange trees. Research Bulletin Ain Shams University, Faculty of Agriculture (No.895). PP28.

Abd-Alla, Manall (2011): Effect of some citrus rootstocks on vegetative growth and leaf mineral content of Baladi lime transplants. M.Sc. Thesis, Fac. of Agric., Ain Shams Univ.

Abdolhossein, A.J., Hasanzada, H. and Farahi, M.H. (2012): Effect of rootstocks type and scion cultivar on citrus leaf total nitrogen. World Applied Sciences Journal 19 (1): 140 - 143.

Alireza, S; Awang,Y., Juraimi, A. and Othman R. (2012): yield and fruit quality of 'Queen' orange [ citrus sinensis $(L)$ Osb.] grafted on different rootstocks in Iran. Australian Journal of crop science, 6 (5): 777-783.

Baldry, J., Dougam J.; Shaked A. and Bor- Akiva, A. (1982): Chemical analysis and taste panel evaluation of the fruit quality of Valencia late oranges on two rootstocks. Journal of Horticultural Science 57(2):233-237.

Bassal, M.A. (2009): Growth, yield and fruit quality of "Marisol" Clementine grown on four rootstocks in Egypt. Scientia Horticultuae. 119:2,132-137.

Blac, C.A. (1965): Method of soil analysis. Amer. Soc. Agron., Madison, Wisconsin, USA.

Brown, J.O. and Lilleland, O. (1966): Rapid determination of potassium and sodium in plant material and soil extracts by Flamephotometery. Proc. Amer. Soc. Hort. Sci. 48:344-346.

Chapman, H.D. and Part, P.F. (1961): Method of Analysis for soils, plant and waters, Univ . California, Div. Agric . Sci. priced pub. 4034. U.S.A.

Davies, F.S. and Albrigo, L.G. (1994): Citrus. Published by CAB International. PP88.

Dawood, S.A. (2001): Growth, yield, fruit quality and leaf mineral content of Valencia orange trees on Sour orange and Volkamer lemon grown on slightly alkaline clay soil. J. Agric. Res. Tanta Unive., 27(4): 726-736.

El-Hammady, A.; Kader A.A. and El-Hammady, M. (1974): Effect of post harvest application of ethephon on artificial degreening of Washington Navel orange - Egypt, J. Hort., 1:39 - 48.

El-Kady, M.I.; Samar, B.N. and Arafat M. (2007): Evaluation of growth and fruiting if Valencia orange trees on different citrus rootstocks. J. Agric. Sci. Mansoura Univ., 32 (8):65516562, Egypt.

El-sayed Somaia A. (1999): Physiological studies on some orange varieties buded on different rootstocks. Ph.D. Thesis, Fac. of Agric., Tanta Univ.

Gregoriou, C. and Economides C.V. (1993): Growth, yield and fruit quality of Nucellar March Grape fruit on fifteen rootstocks in Cyprus. J. Amer. Soc. Hort. Sci 118(3):326-329.

Gregoriou, C. and Economides, C.V. (1994): Growth yield and fruit quality of nuclear Frost Valencia orange on fifteen rootstocks in Cyprus Acta Hort. No.365: 57-68 [.c.f.Hort Abst. 65(6) :5408].

Hafez, O.M. (2006): Evaluation of growth characteristics of some citrus rootstocks protein finger print technique. American. Eurasian. Journal of Agricultural and Environmental Science. 1(3): 243- 248.

Jakson, M.L. (1967): Soil Chemical Analysis, Makhija offset press, New Delhi, India.

Khankahdani, H.H.; Hasanpour, A. and Aboutalebi, A. (2006): Effect of different rootstocks on vegetative growth, dry matter and mineral concentration of Mexican lime (Citrus aurantifolia Swingle). Seed and plant. 22:2, Pel55-Pel66, en 12. 15 ref. Iran

Kitson, R.E. and Mellon, M.C.M. (1964): Colorimetric determination of phosphorus as molyb- 
divando phosphoric acid. Ind-Eng. Chem Anal. Ed. 16: 379-383.

Koles Nikov, V.A. (1971): The root system of fruit plants. Mri publishers. Moscow. 87-102. Methods of Analysis, Washington . D.C.PP.43-428.

Mendilicioglu, K. (1986): A study on the effects of rootstocks on the yield and quality of Satsuma. Ege Universities Ziraat Fakultesi Dergisi, 23 (1): 41- 77 [ c.f Hort. Abst., 59 (2) : 1607].

Monteverde, E.E (1989): Evaluation of Valencia orange on ten rootstocks in high altitude valleys in Carabobo-Yaracuy. I. yields, growth and efficiency. FONAIAP Divulga, 7(31) 6-9. [c.f. Hort. Abst. 62(1): 703].

Monteverde, E.E.; Reyes F.J.; Laborem G. and Ruiz, J.R. (1988): Citrus rootstocks in Venezuela, behavior of Valencia orange on ten rootstocks. Sixth international citrus congress. Middle - East, Tel Aviv, Israel, 6-11 march 1988. Volume 1, Rehovot; B“alaban publishers 4755, [c.f. Hort. Abst. 60(9); 7673].

Morse, J.G and Robertson, C.A. (1987): Calculating canopy area of citrus trees and surface area of fruits. Florida Entomol. 70-189. J. Amer. Soc. Hort. Sci, 115(1) : 6-8.

Nasser, M.A. (2010): Mutual effect of some newly introduced citrus cultivars buded on
Sour-orange and Volkamer rootstocks. B.S.c Thesis, Fac. Agric., Ain shams Univ.

Sayed, R.A.; S.K.M. Abd El-Naby and; Salem, S.E. (2003). Efficiency of some citrus rootstocks under calcareous soil condition. Annalsof-Agriculture. Science. Cairo 48(2): 729 740.

Snedecor, G.M. and Cochran, W.G. (1980): Statistical methods, sixth Edition, lowa State Univ. Prees, Ames . Lowa, U.S.A.

Tuzcu O.; Yildinm, B.; Duzenoglu, S. and Bahceci, I. (1999): Effects of different rootstocks on yield and fruit quality of Washington Navel Moro blood orange. Turkish Journal Agriculture and forestry 23-222 (c.f CAB Abst. 1999).

Valbuena, H. (1994): Agronomic performance of some citrus stock- scion combinations in the middle Zone of the river Guaare, Zulia, Venezuela Revista de la Facultad de Agronomia, Univ. del Zulia 11 (1) -12 [c.f. Hort. Abst. 65 (8) 7408].

Zayan, M.A.; Zeerban, S.M. Ayaad, H.M. Dawood, S.A. and Ennab, H.A. (2004): Evaluation study on Washington Navel orange cultivar budded on five rootstocks. J. Agric, Res. Tanta Univ., 30 (2): 400-420. 